\title{
Fetch-limited barrier islands: Overlooked coastal landforms
}

J. Andrew G. Cooper, Centre for Coastal and Marine Research, School of Environmental Sciences, University of Ulster, Coleraine BT52 1SA, UK, jag.cooper@ulster.ac.uk; David A. Lewis, Nicholas School of the Environment, Duke University, P.O. Box 90228, Durham, NC 27708, USA, dlewis@selcnc. org; and Orrin H. Pilkey, Nicholas School of the Environment, Duke University, P.O. Box 90228, Durham, NC 27708, USA, opilkey@duke.edu.

\section{ABSTRACT}

The barrier islands of sheltered, low-wave energy coastal environments are an important, unstudied, and previously undocumented landform category. Globally, >15,000 such sandy fetch-limited barrier islands exist, compared to only 2200 open-ocean barrier islands. Fetch-limited conditions develop in the sheltered waters of fjords, bays, barrier island lagoons, and behind coral reefs. Fetch-limited barrier islands are typically short $(1 \mathrm{~km})$, narrow $(10-100 \mathrm{~m})$, and low $(1-3 \mathrm{~m})$ relative to ocean barriers and can be divided into approximately equal numbers of active and inactive forms. The inactive islands are locked in by salt marshes or mangroves and are only slightly impacted in the short term by modern marine processes. The evolution of active fetch-limited barrier islands is largely driven by storm events, and the impact of these storms is strongly influenced by the presence of marshes or mangroves.

Islands originate in diverse ways, including alteration of antecedent topography, spit breaching, and onshore transport of sand to marsh rims. Many are relict islands from higher Holocene and Pleistocene sea levels. The abundance of fetchlimited barrier islands is highly variable: 600 islands occur in the $2000 \mathrm{~km}^{2}$ Laguna Madre of México compared to only 65 in the $6600 \mathrm{~km}^{2}$ Pamlico-Albemarle Sound. They have a high geological preservation potential and may have been misidentified in the stratigraphic record because of a lack of appreciation of their morphology and structure. Because of unprecedented development pressure on open-ocean barrier islands, the new frontier of coastal development in the United States and elsewhere may well be these low-energy islands whose formative processes and temporal evolution are virtually unstudied.

\section{INTRODUCTION}

Globally, the length of low-energy shorelines far exceeds that of high-energy shorelines (Jackson et al., 2002); however, the bulk of scientific understanding of shorelines is based on open
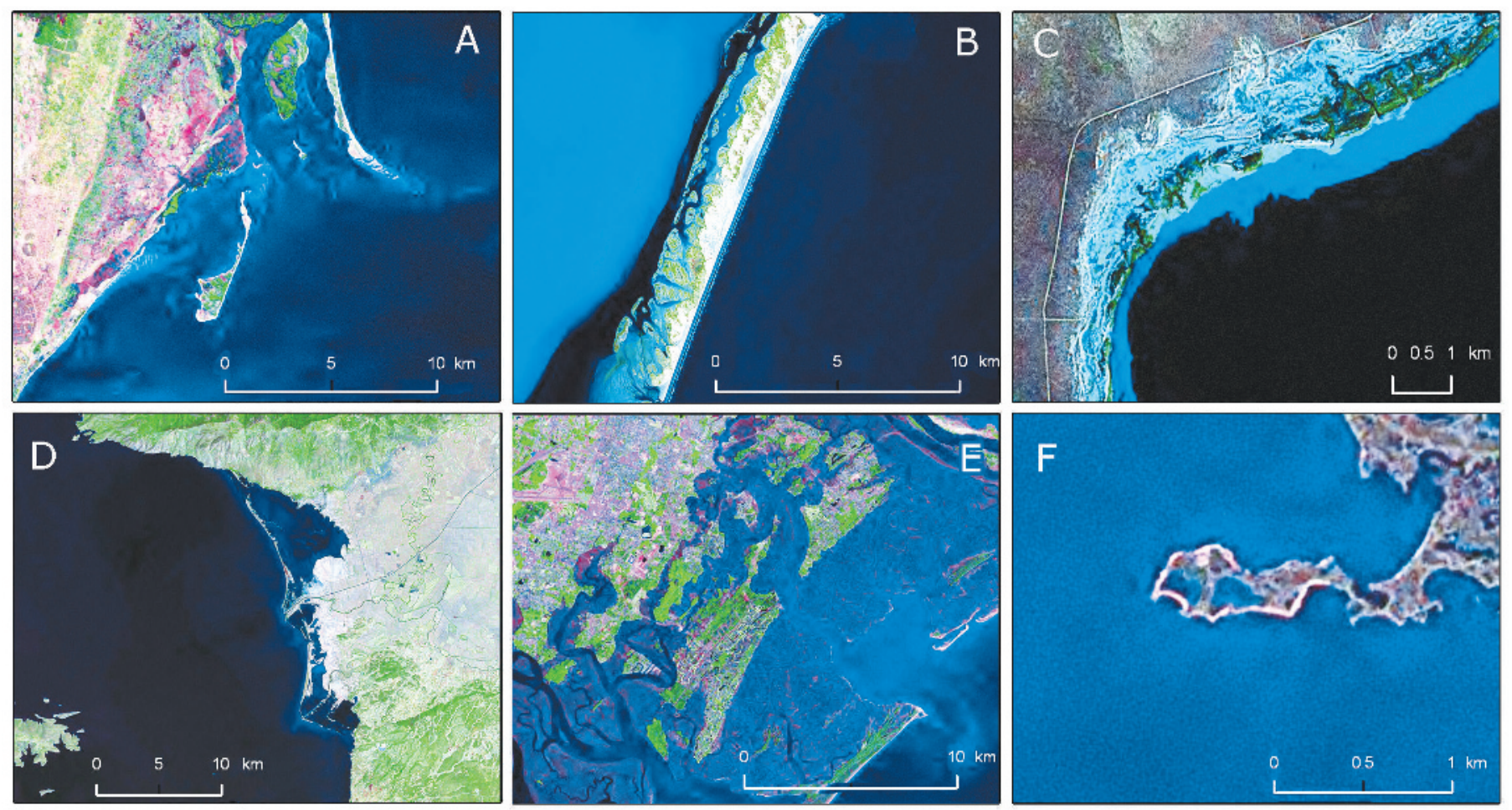

Figure 1. Six examples of fetch-limited barrier islands. (A) Xefina Island, Maputo Bay, Mozambique, probably formed from spit breaching. (B) A chain of fetch-limited barrier islands parallel to the lagoon side of the open ocean barrier of Laguna Madre, México. (C) A sequence of six barrier islands, five of which were stranded by Holocene sea-level fall in the upper Spencer Gulf, Australia. (D) Deltaic fetch-limited barrier islands at the mouth of the Menderes River, western Turkey, in sheltered, rocky bays. (E) An inactive fetch-limited barrier island surrounded by marsh behind the open-ocean barrier islands of Georgia, USA. (F) A wraparound marsh fringe island in Chesapeake Bay, USA. Photos courtesy the National Aeronautic and Space Administration's Earth Science Scientific Data purchase program, LANDSAT 4/5 and 7, https://zulu.ssc.nasa.gov/mrsid (accessed Dec. 2005). 
ocean studies. Around 2200 barrier islands comprise 10\% of the length of the world's open-ocean shoreline (Stutz and Pilkey, 2001), and their evolutionary processes are well studied. In this paper, we report the occurrence of more than 15,000 barrier islands in sheltered, low-energy settings that represent a hitherto unreported type of landform. Investigation of these islands has been bypassed in favor of the larger and societally more important open-ocean barrier islands, which are often subject to intense development pressure (e.g., Miami Beach, USA), while barriers in low-energy settings are seldom developed and then usually only lightly (e.g., Cedar Island, Pamlico Sound, USA). As open-ocean island beaches near development capacity, sheltered islands are becoming increasingly attractive for development purposes. Understanding the processes of island evolution is important for managing future development on these islands. Already, a number of U. S. fetch-limited barrier islands, such as Harkers Island, North Carolina; Johns Island, South Carolina; and Skidaway Island, Georgia, are extensively developed. In South Carolina, bridge-building to fetch-limited islands in coastal lagoons is currently at the forefront of a statewide environmental debate, and plans have been announced at the time of this writing for a massive tourism development on the Laguna Madre of México.

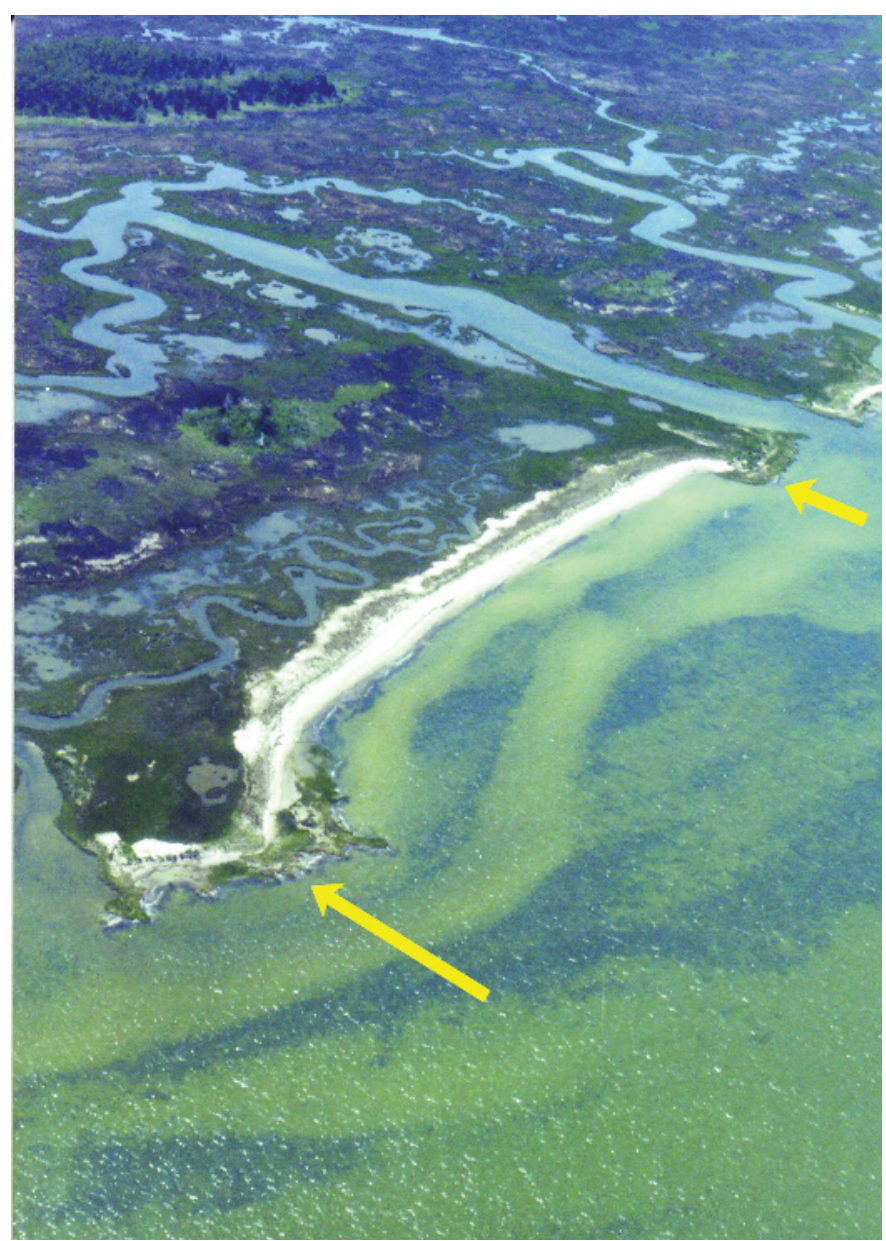

Figure 2. Marsh peat outcrops (marked by arrows) form temporary headlands that control the planform of barrier islands in low-energy settings, such as in this example from Chesapeake Bay.
Fetch-limited barrier islands occur in bays (e.g., Delaware Bay, USA), in back barrier lagoons (e.g., Laguna Madre, México; Fig. 1B), within drowned thermokarst topography (e.g., North Slope, Alaska, USA), in the lee of offshore islands (e.g., Western Turkey; Fig. 1D), or behind coral reefs (e.g., Queensland, Australia). The use of the descriptor "barrier island," modified by the adjective "fetch-limited," is appropriate for these features because the sheltered sand bodies considered in this study have all the components of open-ocean barrier islands as identified by Oertel (1985). The designation "fetch-limited" simply recognizes that these islands are not exposed to openocean high-energy swell wave conditions and that they are affected by only locally generated wind waves. In most cases, the fetch distance over which waves are generated is $<25 \mathrm{~km}$, although in the case of large lagoons like the Pamlico Sound, the largest potential fetch distance is up to $100 \mathrm{~km}$. Following Jackson et al. (2002), we define fetch-limited as areas where waves are usually $<1.0 \mathrm{~m}$ under non-storm conditions.

Some fetch-limited barrier islands are identical in physical appearance to ocean islands (e.g., Xefina Island in Maputo Bay, Mozambique; Fig. 1A). Others are quite irregular in shape or have sharp shoreline angles and corners, usually because of vegetative (salt marsh or mangroves) control of shoreline processes (Lewis et al., 2005, Chesapeake Bay; Fig. 1F). Marsh peat can also form temporary headlands that influence island plan form (Fig. 2). A small number have a near-circular plan view shape because the fetch is similar in all directions.

Fetch-limited barrier islands are found on every continent except Antarctica (Table 1). Like ocean barriers (Glaeser, 1978; Pilkey, 2003), they are found predominantly along trailing edge margins, where large lagoons are common. Nonetheless, as much as $10 \%$ of the world's total is located along active margins (e.g., Golfo de Tehuantepec, México). Fetch-limited barrier islands exist under tidal conditions ranging from megatidal (e.g., King Sound, Australia) to virtually tideless (e.g., Pamlico Sound, USA). They also exist in all types of coastal climates, from the polar Arctic (e.g., Obskaya Guba, Russia) to hot arid regions (e.g., Bardawil lagoon, Egypt), but are most abundant in temperate (e.g., Atlantic Coast, USA) and humid subtropical zones (e.g., Mozambique).

The abundance of fetch-limited barrier islands in a given setting depends on several factors, including the size and bathymetry of the bay, fetch, availability of sand, sea-level history, storm frequency and direction, vegetation, salinity, tidal range, and antecedent morphology. Depending on all these factors, the abundance of islands within lagoons varies considerably. For example, Pamlico-Albemarle Sound, a lagoon of $6600 \mathrm{~km}^{2}$, contains only 65 islands, while the $2000 \mathrm{~km}^{2}$ Mexican Laguna Madre has over 600 islands, the highest density of fetch-limited barrier islands we have observed anywhere.

Fetch-limited barrier islands fall into three main categories: active, inactive, and anthropogenic. Globally, there are approximately the same number (7500) in each of the first two categories.

- Active fetch-limited barrier islands form and continue to evolve (erode, accrete, and migrate) under present sea level and fetch-limited oceanographic conditions.

- Inactive fetch-limited barrier islands (Fig. 1E) are those trapped by salt marshes or mangroves extensive enough 
to protect the islands from most storms. Subaerial processes play an important role in the evolution of these islands.

- Anthropogenic islands comprise mostly dredge spoil piles from the creation of navigation channels. These are globally abundant and are frequently difficult to distinguish from active or inactive islands.

Fetch-limited barriers form by the same mechanisms as ocean-facing barriers; for example, through spit breaching, inundation, erosion of preexisting topography, and sediment inputs from offshore and/or longshore drift. The levels of energy involved in their formation are much lower than those of their open-ocean counterparts; consequently, they are much smaller. Some fetch-limited barrier islands are ancient ocean barrier islands left stranded from a higher sea-level stand (e.g., Roanoke Island, North Carolina). Holocene fetch-limited barrier islands are particularly common in the Southern Hemisphere, where they were stranded as sea level dropped during the past

TABLE 1. GLOBAL DISTRIBUTION OF ACTIVE FETCH-LIMITED BARRIER ISLANDS

\begin{tabular}{|c|c|c|c|c|}
\hline & Number & $\begin{array}{l}\text { Percent } \\
\text { of total }\end{array}$ & $\begin{array}{c}\text { Total } \\
\text { length } \\
(\mathrm{km})\end{array}$ & $\begin{array}{l}\text { Avg. } \\
\text { length } \\
(\mathrm{km})\end{array}$ \\
\hline Northern Hemisphere & 4481 & $63.8 \%$ & 4912 & 1.1 \\
\hline Southern Hemisphere & 2542 & $36.2 \%$ & 2498 & 1.0 \\
\hline Africa & 728 & $10.4 \%$ & 802 & 1.1 \\
\hline Atlantic Ocean & 208 & $3.0 \%$ & 234 & 1.1 \\
\hline Indian Ocean & 83 & $1.2 \%$ & 139 & 1.7 \\
\hline Mediterranean Sea & 9 & $0.1 \%$ & 11 & 1.2 \\
\hline Mozambique Channel & 337 & $4.8 \%$ & 345 & 1.0 \\
\hline Red Sea & 91 & $1.3 \%$ & 73 & 0.8 \\
\hline Australia & 1710 & $24.3 \%$ & 1475 & 0.9 \\
\hline Arafura Sea & 325 & $4.6 \%$ & 332 & 1.0 \\
\hline Gulf of Carpentaria & 65 & $0.9 \%$ & 90 & 1.4 \\
\hline Indian Ocean & 1075 & $15.3 \%$ & 555 & 0.5 \\
\hline Pacific Ocean & 245 & $3.5 \%$ & 498 & 2.0 \\
\hline Eurasia & 2005 & $28.5 \%$ & 2483 & 1.2 \\
\hline Arctic Ocean & 857 & $12.2 \%$ & 1250 & 1.5 \\
\hline Atlantic Ocean & 37 & $0.5 \%$ & 32 & 0.9 \\
\hline Baltic Sea & 22 & $0.3 \%$ & 33 & 1.5 \\
\hline Black Sea & 107 & $1.5 \%$ & 116 & 1.1 \\
\hline Indian Ocean & 506 & $7.2 \%$ & 460 & 0.9 \\
\hline Mediterranean Sea & 160 & $2.3 \%$ & 194 & 1.2 \\
\hline North Sea & 3 & $0.0 \%$ & 4 & 1.3 \\
\hline Pacific Ocean & 231 & $3.3 \%$ & 295 & 1.3 \\
\hline Persian Gulf & 58 & $0.8 \%$ & 58 & 1.0 \\
\hline Red Sea & 1 & $0.0 \%$ & 2 & 2.0 \\
\hline South China Sea & 23 & $0.3 \%$ & 39 & 1.7 \\
\hline North America & 2181 & $31.1 \%$ & 2109 & 1.0 \\
\hline Arctic Ocean & 378 & $5.4 \%$ & 489 & 1.3 \\
\hline Atlantic Ocean & 485 & $6.9 \%$ & 400 & 0.8 \\
\hline Beaufort Sea & 77 & $1.1 \%$ & 124 & 1.6 \\
\hline Bering Sea & 30 & $0.4 \%$ & 34 & 1.1 \\
\hline Caribbean Sea & 21 & $0.3 \%$ & 24 & 1.1 \\
\hline Gulf of California & 108 & $1.5 \%$ & 99 & 0.9 \\
\hline Gulf of Mexico & 818 & $11.6 \%$ & 656 & 0.8 \\
\hline Pacific Ocean & 264 & $3.8 \%$ & 283 & 1.1 \\
\hline South America & 399 & $5.7 \%$ & 541 & 1.4 \\
\hline Atlantic Ocean & 286 & $4.1 \%$ & 373 & 1.3 \\
\hline Caribbean Sea & 91 & $1.3 \%$ & 114 & 1.3 \\
\hline Pacific Ocean & 22 & $0.3 \%$ & 54 & 2.5 \\
\hline Total & 7023 & & 7410 & 1.1 \\
\hline
\end{tabular}

2000-4000 yr. For example, in Spencer Gulf, Australia (Fig. 1C), there are up to six lines of fetch-limited barrier islands behind an active seaward island, each at a slightly lower elevation in a seaward direction. In this situation, the landward islands may still be active during high tides and storms, but many such islands are now isolated from their formative processes by the most recent barrier islands. Some fetch-limited barrier islands are surrounded by salt marsh (e.g., Skidaway Island, Georgia) or mangroves (e.g., Mangoky River Delta, Madagascar) and are essentially inactive, while others remain subject to periodic wave reworking under fetch-limited conditions.

The findings reported here relate only to the world's 7500 active islands and are based on analysis of satellite imagery, charts, maps, aerial photos, and field reconnaissance of more than a dozen fetch-limited coastal environments, including sites in Turkey, Mozambique, Australia, México, and the USA. Our goal is to provide a global perspective on the morphology, origin, and distribution of these islands as revealed by our ongoing research program.

\section{ISLAND CHARACTERISTICS AND CONTROLS}

Fetch-limited barrier islands are typically short $(1 \mathrm{~km})$, narrow $(10-100 \mathrm{~m})$, and low $(1-3 \mathrm{~m})$. Fifty meters is an arbitrary minimum island length established in the study, although many islands smaller than this exist. The average island length of the 105 islands along the shores of Delaware Bay, USA, is $1.1 \mathrm{~km}$, compared to an average length of $0.4 \mathrm{~km}$ for the 340 islands in Spencer Gulf, Australia (Fig. 1C). The longest island in Delaware Bay is $20 \mathrm{~km}$; the shortest is just $100 \mathrm{~m}$. Likewise, the longest island in the Spencer Gulf is $8 \mathrm{~km}$; the shortest is $50 \mathrm{~m}$. By contrast, the average lengths of Texas and North Carolina ocean barriers are $54 \mathrm{~km}$ and $21 \mathrm{~km}$, respectively. The small size is attributed to several factors, including low availability of sediment, shallow depths of wave penetration on the shoreface, infrequency of sedimentary activity, limited height of wave runup and hence overwash, and limited accommodation space. These factors combine to produce thin, linear sand accumulations in a low-energy setting.

Inlets and tidal deltas are less important in the evolution of fetch-limited islands compared to those in open-ocean settings. Ebb tidal deltas, when present, are usually small, extending seaward a few tens of meters, and flood tidal deltas are generally absent altogether (Fig. 3). Inlet migration and the formation of new inlets do occur but are not common (Fig. 4).

Islands can exist in a number of different locations within the fetch-limited environment, including immediately behind ocean inlets (e.g., Tapora Bank, New Zealand), fringing marginal salt marshes (e.g., Neuse River Estuary, USA), on the rim of deltas that empty into bays (e.g., Menderes Delta, Turkey; Fig. 1D), and in spectacular chains lagoonward of and parallel to oceanic barriers (e.g., Laguna Madre, México; Fig. 1B).

Orientation of low fetch-limited barrier islands can be highly variable, much more so than ocean-facing islands, because relatively significant fetch may come from almost any direction (Fig. 5). Lagoon bathymetry (shoals and deeps) and patches of vegetation may determine effective fetch. Often there is a strong vegetative control on island planform that may be locally more important than fetch or dominant wind direction. The ends of some fetch-limited barrier islands are highly curved, 

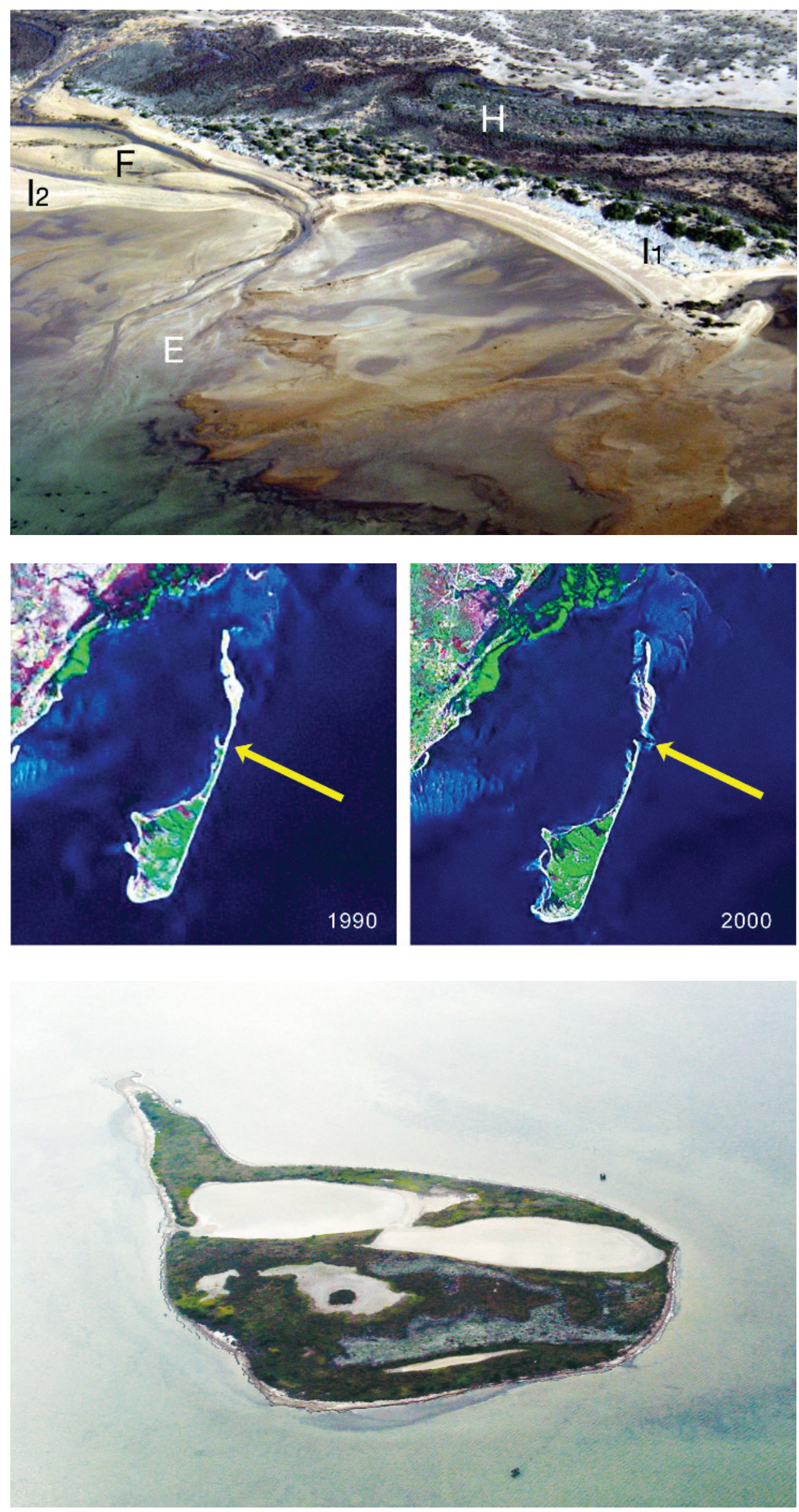

Figure 5. Island in central Laguna Madre, Tamaulipas, México, affected by wave approach from two sides. The resulting fetchlimited sandy barriers, which face opposite directions, have enclosed a central lagoon.
Figure 4. Satellite images from 1990 and 2000 record the formation of a tidal inlet and ebb delta (arrowed) in Xefina Island, Maputo Bay, Mozambique. The southern, landward margin of the island also shows evidence of modification during this period. Unvegetated sand is white; vegetation is green. Photos courtesy the National Aeronautic and Space Administration's Earth Science Scientific Data purchase program, LANDSAT 4/5 and 7, https://zulu.ssc.nasa.gov/mrsid (accessed Dec. 2005). 
a reflection of variable and even opposing fetch directions (e.g., Tangier Island, Chesapeake Bay, USA), but the islands may also form chains with little curvature of individual islands (e.g., Gulf of Ob, Russia; Delaware Bay, USA). In macro- and megatidal environments some fetch-limited islands are only intermittently surrounded by water; at low tide, they are surrounded by intertidal flats. Some are backed by supratidal flats that are cyclically flooded on a spring tide and/or storm and/ or seasonal basis, and mangroves are commonly found seaward of the islands (e.g., Gulf of St. Vincent, Australia; Maputo Bay, Mozambique).

Processes that form and maintain fetch-limited barrier islands are the same as those on open-ocean islands, but their relative importance as well as their absolute magnitude are different. In a bay or lagoon with restricted fetch, the direction of locally generated wind waves is the dominant dynamic variable, similar to low-energy beaches (Jackson et al., 2002). The evolution of fetch-limited barrier islands is strongly dependent upon storms because wave energy is too low to induce much change under fair-weather conditions. For example, according to Jennings and Coventry (1973), physical changes in the intermittent islands of Point Torment, Australia (surrounded by water only at high tides), take place only during typhoons, which occur once every five years on average.

Widening of the fetch-limited islands occurs primarily by storm-driven overwash and/or beach ridge formation and, like all barriers, lengthening is accomplished by alongshore currents. Extensive dune formation is rare, and many islands lack dunes entirely. An important exception to the rule of minor dune formation is islands inside lagoons at the mouth of ocean barrier island inlets, where dunes with heights up to $10 \mathrm{~m}$ (e.g., Bogue Sound, North Carolina) may develop.

Biological control on fetch-limited island morphology is much more important than on ocean-facing barriers. For example, salt marshes, sea grasses, and mangroves can grow in front of and behind active fetch-limited barrier islands, acting to stabilize the islands, baffling the impact of storm waves, and encouraging sediment accumulation (Fig. 6). In addition, preexisting salt marshes (Chesapeake Bay, USA) and mangroves (Maputo Bay, Mozambique) commonly provide platforms for island development. Sand accumulated along the margins of a patch of salt marsh results in the circular shape of some islands in the southern Chesapeake Bay, USA. Such biological control is seldom seen on open-ocean islands because greater wave energy prevents establishment of salt marshes and mangroves on the seaward margin of barrier islands. Salinity probably plays an additional role in island evolution through its control on the type and abundance of vegetation. Under high salinity conditions, such as existed in Laguna Madre, México, before artificial inlets were constructed through the ocean barrier chain (Tunnel and Judd, 2002), vegetative control was likely less important and physical processes more dominant than at present.

Existing topographic features frequently provide the sand supply and the initial base for islands to form. Such geologic control is afforded by a variety of topographic irregularities, such as drowned natural river levees (e.g., Manzala Lagoon, Nile Delta, Egypt), rims of Carolina Bays (e.g., Chesapeake Bay, USA), Pleistocene barrier islands (e.g., Cedar Island,

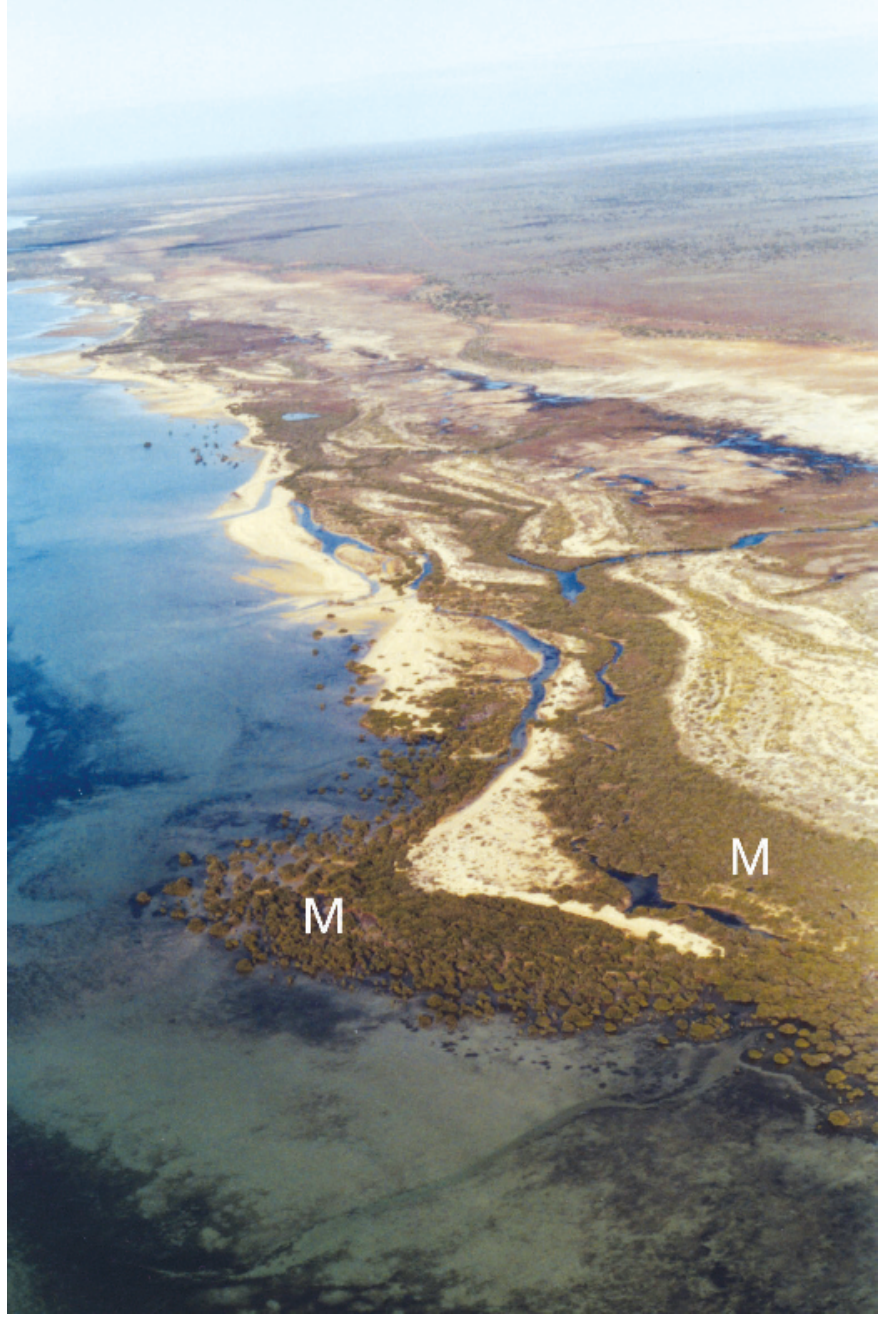

Figure 6. Dense mangrove stands $(M)$ developed in front of and behind islands, upper Spencer Gulf, South Australia.

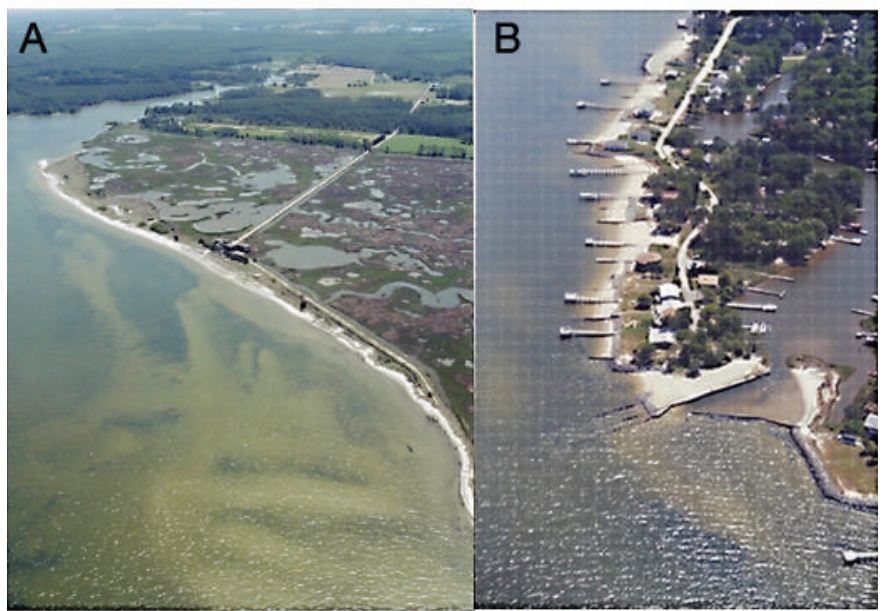

Figure 7. (A) Small-scale development on low-energy barrier island in Chesapeake Bay has been facilitated by construction of a causeway. The scale of development on the adjacent Maryland coast (B) of Chesapeake Bay shows the demand for development in such settings. 
Pamlico Sound, USA), drowned dune fields (e.g., King Sound, Australia), and overwash fans at the back of the open-ocean barriers (e.g., Laguna Madre, México). With time, the original drowned topographic feature may be altered beyond recognition. For example, the "clay dunes" (Price, 1963) of Laguna Madre are being eroded and their sediment reworked into new islands under contemporary wave action.

\section{GEOLOGICAL SIGNIFICANCE}

The preservation potential of these features is high because the infrequency of wave activity enhances the possibility of overstepping and in situ drowning and burial by fine-grained lagoonal sedimentation under rapid transgressive situations. During sea-level fall, the stranding of islands (as in the Spencer Gulf) that are flanked by high tidal flat and supratidal sedimentary environments also provides a relatively high preservation potential as the islands are blanketed by high marsh facies. It is entirely possible that thin beds of sand within lagoonal facies recorded in the geological record and interpreted as creek point bars, tidal deltas, and stream mouth bars represent former fetch-limited barrier islands. They do contain distinctive internal sedimentary structures that, in combination with their gross geometry and setting, should enable identification in the geological record.

\section{THE FUTURE}

Few fetch-limited barrier islands are intensively developed, although many have small-scale habitation (Fig. 7A). Fetchlimited islands are likely to be subjected to development pressure in the immediate future because ocean-facing barrier islands in the first world are already extensively developed, and there is great demand for coastal land even in low-energy environments (Fig. 7B). The environmental and social impact of development of these low-energy islands will differ from that of their ocean-facing counterparts in several ways. Construction at low elevations, which typifies such islands, is a hazard from the standpoint of storm surges. The loss of a beach due to seawall emplacement may turn out to be more societally acceptable for seldom-used lagoon beaches, but the potential for damage to marshes from such seawalls is locally very high. Beach nourishment to restore eroded fetch-limited island beaches will probably be much less costly because of lower wave energies. In addition to these predictable responses, there will likely be unexpected impacts: the lack of knowledge of these features precludes their identification at this stage. Because of the imminent threat of development, however, it is important to rapidly increase our understanding of the complex and widely variable evolutionary processes of these islands.

\section{REFERENCES CITED}

Glaeser, J.D., 1978, Global distribution of barrier islands in terms of tectonic setting: The Journal of Geology, v. 86, p. 283-297.

Jackson, N.L., Nordstrom, K.F., Eliot, I., and Masselink, G., 2002, Low energy sandy beaches in marine and estuarine environments: a review: Geomorphology, v. 48, p. 147-162, doi: 10.1016/S0169-555X(02)00179-4

Jennings, J.N., and Coventry, R.J., 1973, Structure and texture of a gravelly barrier island in the Fitzroy Estuary, Western Australia and the role of mangroves in the shore dynamics: Marine Geology, v. 15, no. 3, p. 145-167, doi: 10.1016/00253227(73)90063-7.

Lewis, D.A., Cooper, J.A.G., and Pilkey, O.H., 2005, Fetch limited barrier islands of Chesapeake Bay and Delaware Bay: Southeastern Geology, v. 44, p. 1-17.

Oertel, G.F., 1985, The barrier island system: Marine Geology, v. 63, p. 1-18, doi: 10.1016/0025-3227(85)90077-5.

Pilkey, O.H., 2003, Celebration of the World's Barrier Islands: New York, Columbia University Press, 309 p.

Price, W.A., 1963, Physiochemical and environmental factors in clay dune genesis: Journal of Sedimentary Petrology, v. 33, p. 766-778.

Stutz, M.L., and Pilkey, O.H., 2001, A review of global barrier island distribution: Journal of Coastal Research, Special Issue 34, ICS 2000 Proceedings, p. 15-22.

Tunnel, J.W., and Judd, F.W., 2002, The Laguna Madre of Texas and Tamaulipas: Corpus-Christi, Texas, Texas A\&M University Press, 372 p.

Manuscript received 7July 2006; accepted 13 December 2006.
THE GEOLOGICAL SOCIETY

OF AMERICA
Special Paper 416

\section{Paleoenvironmental Record and Applications of Calcretes and Palustrine Carbonates}

Edited by Ana María Alonso-Zarza and Lawrence H. Tanner SPE416, 248 p., ISBN-10: 0-8137-2416-3; ISBN-13: 978-0-8137-2416-4

GSA Sales and Service

P.O. Box 9140, Boulder, CO 80301-9140, USA $+1-303-357-1000$, option 3

$+1-888-443-4472 \bullet$ Fax +1-303-357-1071

www.geosociety.org/bookstore/

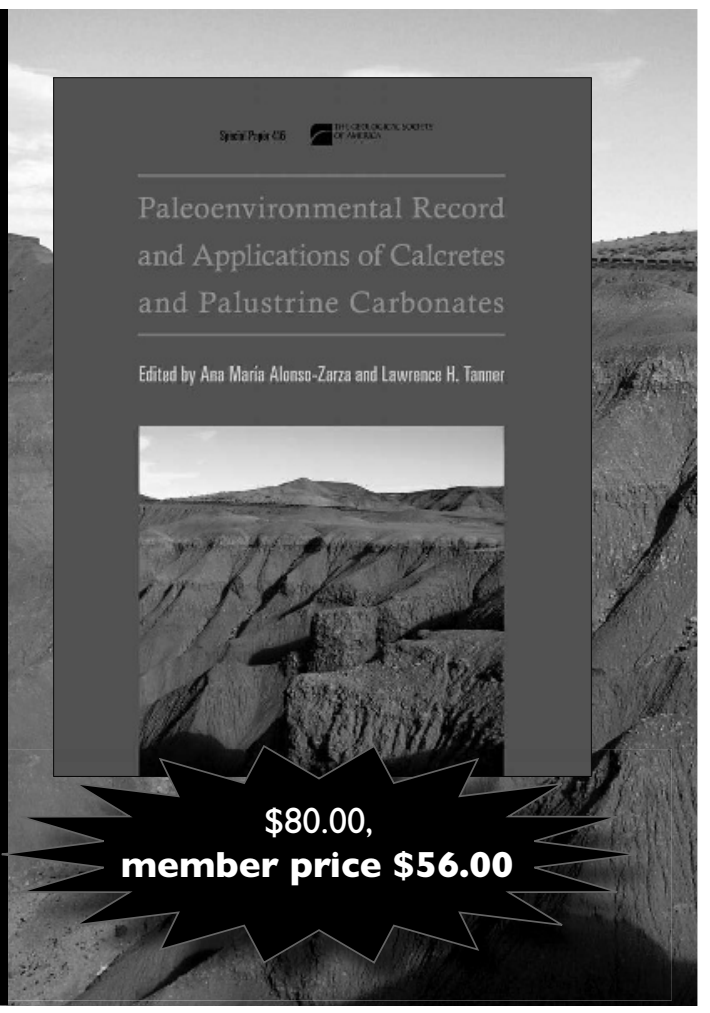

